\title{
WANPRESTASI TERHADAP AKTA PENGAKUAN UTANG DIBAWAH TANGAN DENGAN JAMINAN SERTIFIKAT HAK MILIK ATAS TANAH DITINJAU DARI PASAL 12 UNDANG-UNDANG NOMOR 4 TAHUN 1996 TENTANG HAK TANGGUNGAN (Analisis Putusan Kasasi Nomor 837 K/Pdt/2019)
}

\author{
${ }^{1}$ Aria Dimas Harapan, ${ }^{2}$ Andi Safira Yan Istiany \\ Fakultas Hukum Universitas Pamulang. \\ Email : Asafirasistianv2112@gmail.com
}

Received: Juli 2020/Revised: Juli 2020 /Accepted: Agustus 2020

\begin{abstract}
ABSTRAK
Bertitik tolak dari kebutuhan akan modal, pada prakteknya sebagian masyarakat enggan untuk melakukan kredit dengan Bank, dengan alasan prosesnya yang dianggap sulit, dan terlalu berbelit-belit. Sebab itu, sebagian masyarakat lebih memilih untuk meminjam sejumlah uang kepada orang pribadi atau yang lebih dikenal dengan utang piutang. Berbicara mengenai perjanjian utang piutang maka akan sangat berkaitan dengan jaminan karena setiap kreditur membutuhkan rasa aman atas dana yang dipinjamkannya. Penelitian ini penulis buat untuk mengkaji serta mengetahui upaya yang dapat dilakukan jika terjadi wanprestasi dalam surat pengakuan utang dibawah tangan yang menjaminkan sertifikat hak milik atas tanah tanpa didahului perjanjian pokok, serta pertimbangan hakim (Ratio Decidendi) dalam Putusan Kasasi Nomor 837K/Pdt/2019 tentang wanprestasi dalam surat pengakuan utang. Metode penelitian yang digunakan dalam penelitian ini berupa pendekatan yuridis normatif yang bersifat deskriptif, yaitu penelitian yang mengacu kepada normanorma hukum yang terdapat dalam peraturan per undang-undangan dan putusan pengadilan. Hasil penelitian yang diperoleh penulis dalam penelitian ini adalah pertama pertimbangan hakim dalam memutus Perkara Nomor 837/K/Pdt/2019 kurang tepat karena secara teori putusan hakim tersebut mengesampingkan kepastian hukum atas suatu perkara perdata dengan memutus wanprestasi terhadap surat pengakuan utang, yang kemudian hakim juga menyatakan pula batal demi hukum terhadap surat pengakuan utang tersebut. Dimana berdasarkan ketentuan Pasal 12 Undang-Undang Nomor 4 Tahun 1996 tentang Hak Tanggungan, jaminan yang menjadi objek dalam penelitian penulis, merupakan suatu sebab terlarang yang bertentangan dengan syarat sahnya suatu perjanjian, sehingga sudah
\end{abstract}


sepatutnya akibat hukum batal demi hukum dijatuhi sedari awal tanpa harus menjatuhi wanprestasi terlebih dahulu dalam akta pengakuan utang tersebut. Sehingga saran penulis perlulah bagi para pihak yang ingin melakukan kegiatan pinjam meminjam terutama dalam hal utang piutang, terlebih dahulu memahami setiap aturan dan norma hukum yang berlaku atas perbuatannya, sehingga tidak akan menimbulkan kerugian diantara para pihak yang mengikatkan diri dikemudian hari.

Kata Kunci: Utang Piutang, Akta Pengakuan Utang, Jaminan, Sertifikat Hak Milik

\section{ABSTRACT}

Starting from the need for capital, in practice some people are reluctant to make credit with banks, because the process is considered difficult, and too convoluted. Therefore, some people prefer to borrow a certain amount of money from individuals or what is better known as debt or credit. Talking about the debt and credit agreement, it will be closely related to collateral because every creditor needs a sense of security for the funds he lends. The author's research is made to examine and find out what efforts can be made if there is default in an underhand debt acknowledgment that guarantees the title of title to land without being preceded by a principal agreement, as well as the judge's consideration (Ratio Decidendi) in the Cassation Decision Number 837K / Pdt / 2019 concerning default in the debt acknowledgment. The research method used in this study is a descriptive normative juridical approach, namely research that refers to the legal norms contained in statutory regulations and court decisions. The results of the research obtained by the author in this study are the first consideration of the judge in deciding Case Number 837 / K / Pdt / 2019 is not quite right because in theory the judge's decision overrides legal certainty for a civil case by deciding in default of a debt acknowledgment, which then the judge also also declared null and void the debt acknowledgment. Where based on the provisions of Article 12 of Law Number 4 of 1996 concerning Mortgage Rights, the guarantee which is the object of the author's research, is a forbidden cause that is contrary to the validity of an agreement, so that the legal consequences are null and void from the start without having to obey prior default in the debt recognition deed. So that the author's suggestion is necessary for parties who want to carry out lending and borrowing activities, especially in terms of debt and credit, first 
Aria Dimas Harapan \& Andi Safira Yan Istiany,

understand any rules and legal norms that apply to their actions, so that they will not cause losses among the parties who bind themselves in the future.

Keywords: Accounts Receivable, Deed of Debt Recognition, Guarantee, Certificate of Ownership

\section{PENDAHULUAN}

Pembangunan perekonomian nasional telah banyak perkembangan terlebih setelah mengalami krisis moneter ditahun 1998 lalu, melihat Indonesia sedang berada ditahap terendah dari perekonomiannya pada kala itu. Sebagai akibat dampak krisis moneter dan krisis ekonomi yang dialami negara Indonesia pada era sekitar pertengahan tahun 1997, terdapat banyak kejadian atau peristiwa penting yang terkait dengan beberapa bank di Indonesia, baik bank milik pemerintah maupun bank milik swasta nasional. Bertitik tolak dari kebutuhan akan modal tersebut, pada prakteknya sebagian masyarakat justru enggan untuk melakukan kredit dengan Bank, dengan alasan prosesnya yang dianggap sulit dan terlalu berbelit-belit. Sebagian masyarakat juga menghindari proses kredit dengan bank, karena dianggap bunga yang dikenakan terlalu tinggi, prosedur terlalu rumit, resiko takut tidak dapat melunasi utang, tidak berpengalaman dalam urusan bank, dan sebagian orang merasa khawatir akan sistem riba. (Riky, 2008)

Oleh sebab itu, sebagian masyarakat lebih memilih untuk meminjam sejumlah uang kepada orang pribadi atau yang lebih dikenal dengan utang piutang. Utang menurut Kamus Besar Bahasa Indonesia, yaitu uang yang dipinjamkan dari orang lain. (Poerwadarminto, 2001) Sedangkan piutang mempunyai arti uang yang dipinjamkan (dapat ditagih dari orang lain). Utang piutang sendiri merupakan perjanjian antara para pihak yang satu dengan pihak lainnnya yang mana objek yang diperjanjikan pada umumnya adalah berupa uang. Dimana kedudukan pihak yang satu sebagai pihak yang memberikan pinjaman (kreditur), sedangkan pihak yang lain adalah pihak yang menerima pinjaman uang tersebut (debitur). Dan sudah sepatutnya uang yang menjadi objek utang piutang tersebut akan dikembalikan dalam jangka waktu tertentu sesuai yang diperjanjikannya. (Muhamad, 2010)

Berbicara mengenai perjanjian utang piutang maka akan sangat 
berkaitan dengan jaminan karena setiap kreditur membutuhkan rasa aman atas dana yang dipinjamkannya. Sejumlah uang yang diberikan oleh kreditur perlu dilindungi demi mencapai suatu kepercayaan kreditur. Tanpa adanya pengamanan tersebut, kreditur akan sulit mengelakkan resiko yang akan datang, sebagai akibat tidak berprestasinya debitur. Untuk mendapat kepastian dan keamanan dari debitur dalam pembayaran cicilan/angsuran, kreditur melakukan tindakan-tindakan pengamanan/perlindungan dan meminta kepada debitur agar mengikatkan suatu barang tertentu sebagai jaminan dalam perjanjian utang-piutang tersebut. (TjeAman), 1989)

Untuk pinjaman yang relatif besar maka tanah menjadi jaminan yang umum dalam utang piutang. Hal itu dilakukan karena nilai tanah selalu baik dan tanah dalam kehidupan manusia mempunyai arti yang penting. Tanah dapat dinilai sebagai suatu harta yang mempunyai sifat permanen karena memberikan suatu kemantapan untuk dicadangkan sebagai investasi bagi kehidupan manusia di masa yang akan datang mengingat fungsi tanah sebagai sarana untuk memenuhi kebutuhan dasar manusia. (Kartika, 2012)

Dalam Undang-undang Hak Tanggungan diatur bahwa untuk melidungi hak kreditor apabila debitur wanprestasi adalah melalui eksekusi Hak Tanggungan. Apabila debitur cidera janji, pemegang Hak Tanggungan pertama mempunyai hak menjual objek Hak Tanggungan atas kekuasaan sendiri melalui pelelangan serta mengambil pelunasan piutangnya dari hasil penjualan tersebut. (Dermawan, 2018) Yang mana perlu diperhatikan lebih jauh, tanah sebagai jaminan atas utang telah diatur dalam Undang-undang Nomor 4 Tahun 1996 Tentang Hak Tanggungan beserta benda-benda yang berkaitan dengan tanah. Sesuai dengan ketentuan Pasal 1 angka (1) Undang-undang Nomor 4 Tahun 1996 tentang Hak Tanggungan maka hak atas tanah yang dijadikan jaminan untuk pelunasan utang tertentu harus dilakukan pembebanan Hak Tanggungan terlebih dahulu yang dibuat oleh Pejabat Pembuat Akta Tanah (PPAT) dengan melalui proses sesuai dengan yang ditentukan dalam Undang-undang tersebut diatas. Serta Pasal 12 Undang-undang Nomor 4 Tahun 1996 tentang Hak Tanggungan (UUHT) menyatakan bahwa; "Janji yang memberikan kewenangan kepada pemegang hak tanggungan untuk memiliki hak tanggungan apabila debitur cidera janji, batal demi hukum". 


\section{RUMUSAN MASALAH}

1. Bagaimanakah upaya yang dapat dilakukan jika terjadi wanprestasi dalam surat pengakuan utang dibawah tangan yang dibuat yang menjaminkan sertifikat hak milik atas tanah tanpa didahului perjanjian pokok dan hak tanggungan?

2. Bagaimanakah pertimbangan hakim (Ratio Decidendi) dalam Putusan Kasasi Nomor 837K/Pdt/2019 tentang wanprestasi dalam pengakuan utang piutang dibawah tangan yang menjaminkan sertifikat hak milik atas tanah sudah sesuai dengan Pasal 12 Undang-undang Nomor 4 Tahun 1996 Tentang Hak Tanggungan?

\section{METODE PENELITIAN}

\section{Jenis Penelitian}

Jenis penelitian ini merupakan penelitian hukum yuiridisnormatif, yaitu penelitian yang mengacu kepada norma-norma hukum yang terdapat dalam peraturan perUndang-undangan dan putusan pengadilan. Sumber utama dalam penelitian adalah banyak menggunakan bahan hukum sekunder sebagai acuannya, ditambah dengan bahan hukum primer.

2. Pendekatan Masalah

Pendekatan masalah yang digunakan dalam penelitian merupakan pendekatan yuridis normatif Pendekatan yuridis normatif adalah pendekatan masalah dengan melihat, menelaah dan menginterpretasikan hal-hal yang bersifat teoritis yang menyangkut asas-asas hukum yang berupa konsepsi, peraturan perUndang-undangan, pandangan, doktrin hukum dan sistem hukum yang berkaitan. Jenis pendekatan ini menekankan pada diperolehnya keterangan berupa naskah hukum yang berkaitan dengan objek yang diteliti.

3. Spesifikasi Penelitian

Spesifikasi penelitian yang digunakan dalam skripsi ini adalah penelitian deskriptif yang bersifat pemaparan/memaparkan dan bertujuan untuk memperoleh gambaran (deskripsi) lengkap tentang keadaan hukum yang berlaku, mengenai gejala yuridis yang ada, atau peristiwa hukum tertentu yang terjadi didalam masyarakat. (Rahardjo, 2000)

4. Jenis Data

Penulisan skripsi ini menggunakan data sekunder dikarenakan jenis metode penelitiannya merupakan penelitian normatif, yang mana data sekunder merupakan data yang diperoleh dari hasil 
penelaahan kepustakaan atau penelaahan terhadap berbagai literatur atau bahan pustaka yang sering disebut sebagai bahan hukum.

5. Analisis Data

Analisis yang digunakan adalah analisis deskriptif kuantitatif yaitu menyajikan kajian pada data-data yang diperoleh dari literatur kepustakaan, doktrin, maupun artikel terkait dalam penelitian. Suatu penelitian deskriptif dimaksudkan untuk memberikan data yang seteliti mungkin tentang manusia, keadaan atau gejala-gejala lainnya. (Soekanto, 2007) Berdasarkan hasil analisis ditarik kesimpulan secara dedukatif, yaitu cara berpikir yang didasarkan pada fakta-fakta yang bersifat umum untuk kemudian ditarik suatu kesimpulan bersifat khusus.

\section{PEMBAHASAN}

\section{Tinjauan Umum Perjanjian}

Dalam Kamus Besar Bahasa Indonesia, perjanjian adalah "persetujuan tertulis atau dengan lisan yang dibuat oleh dua pihak atau lebih, masing- masing bersepakat akan mentaati apa yang tersebut dalam persetujuan itu." (Departemen Pendidikan Nasional, 2005) Menurut Prof. Subekti, perjanjian yaitu suatu peristiwa di mana seorang berjanji kepada seorang lain atau dimana dua orang itu saling berjanji untuk melaksanakan sesuatu hal. (Subekti, 2004)

Sudikno Mertokusumo memberikan pengertian perjanjian sebagai hubungan hukum antara dua pihak atau lebih berdasarkan kata sepakat untuk menimbulkan akibat hukum. (Suryono, 2014)

Dari rumusan perjanjian tersebut dapat disimpulkan, bahwa unsurunsur perjanjian itu adalah: (Simanjuntak, 2015)

1. Ada para pihak;

2. Ada persetujuan antara pihak-pihak tersebut;

3. Ada tujuan yang akan dicapai;

4. Ada prestasi yang akan dilaksanakan;

5. bentuk tertentu, baik lisan maupun tulisan;

6. Ada syarat-syarat tertentu.

Lebih lanjutnya mengenai unsur perjanjian, dalam perkembangan ilmu hukum, unsur perjanjian dapat digolongkan menjadi 2, yaitu;

\section{Essentialia}

Unsur essentialia adalah unsur yang mutlak harus ada bagi 
terjadinya perjanjian.Unsur ini mutlak harus ada agar perjanjian itu sah, merupakan syarat sahnya perjanjian.

\section{Naturalia}

Unsur naturalia merupakan unsur yang lazimnya melekat pada perjanjian, yaitu unsur yang tanpa diperjanjikan secara khusus dalam perjanjian secara diam-diam dengan sendirinya dianggap ada dalam perjanjian karena sudah merupakan pembawaaan atau melekat pada perjanjian.

Dalam naskah asli (bahasa belanda) Pasal 1320 KUH Perdata tidak dirumuskan dengan kata-kata "syarat sahnya perjanjian", tetapi dengan kata-kata "syarat adanya perjanjian" (bestaanbaarheid der overeenkomsten). Perumusan kalimat "syarat adanya perjanjian" tersebut kurang tepat. Dikatakan tidak tepat karena adakalanya suatu perjanjian tidak memenuhi salah satu syarat yang ditentukan Pasal 1320 KUH Perdata tersebut, tetapi tidak mengakibatkan batalnya atau tidak sahnya perjanjian.

Empat syarat yang menjadikan suatu perjanjian menjadi sah dapat dilihat berdasarkan ketentuan Pasal 1320 KUH Perdata, yang berbunyi; "Supaya terjadi persetujuan yang sah, perlu dipenuhi empat syarat.

1. Kesepakatan mereka yang mengikatkan dirinya.

2. Kecakapan untuk membuat suatu perikatan.

3. Suatu pokok persoalan tertentu.

4. Suatu sebab yang tidak terlarang."

Apabila salah satu pihak melakukan perbuatan ingkar atas janjinya, maka pihak yang ingkar akan dinyatakan wanprestasi. Wanprestasi terdapat dalam Pasal 1243 KUH Perdata, yang menyatakan bahwa: "Penggantian biaya, rugi dan bunga karena tidak dipenuhinya suatu perikatan, barulah mulai diwajibkan, apabila si berutang, setelah dinyatakan lalai memenuhi perikatannya, tetap melalaikannya, atau jika sesuatu yang harus diberikan atau dibuatnya, hanya dapat diberikan atau dibuatnya, hanya dapat diberikan atau dibuat dalam tenggang waktu yang telah dilampaukannya".

Kata lain wanprestasi juga dapat diartikan suatu perbuatan ingkar janji yang dilakukan oleh salah satu pihak yang tidak melaksanakan isi perjanjian, isi ataupun melaksanakan tetapi terlambat atau melakukan apa yang sesungguhnya tidak boleh 
dilakukannya. Menurut Prof.Subekti, wanprestasi (kelalaian atau kealpaan) seorang debitur dapat berupa empat macam, yaitu: (Subekti, 2004)

a. Tidak melakukan apa yang disanggupi akan dilakukannya;

b. Melaksanakan apa yang dijanjikannya, tetapi tidak sebagaimana di janjikannya;

c. Melakukan apa yang dijanjikannya tetapi terlambat;

d. Melakukan sesuatu yang menurut perjanjian tidak boleh dilakukannya.

Hukuman atau akibat-akibat yang diterima oleh debitur yang

lalai dalam prestasinya yaitu diantaranya: (Subekti, 2004)

a. Pemenuhan Perjanjian;

b. Pemenuhan Perjanjian Disertai Ganti Rugi;

c. Ganti Rugi Saja;

d. Pembatalan Perjanjian;

e. Pembatalan Disertai Ganti Rugi.

\section{Akta Pengakuan Utang Dengan Jaminan Sertifikat Hak Milik}

1. Akta Pengakuan Utang

Akta Pengakuan Utang adalah suatu akta yang berisi pengakuan utang sepihak, dimana Debitur mengakui bahwa dirinya mempunyai kewajiban membayar kepada Kreditur sejumlah uang dengan jumlah yang pasti (tetap). Tidak ada definisi tersendiri mengenai Akta Pengakuan Utang. Dalam dunia hukum, masyarakat lebih mengenal dengan istilah perjanjian kredit. (Kartika F. N., 2012)

Pengertian Akta Pengakuan Utang dibawah tangan sendiri menurut Pasal 1878 KUH Perdata adalah akta tentang perikatan utang harus dibuat secara sepihak dan ditulis oleh si penandatangan sendiri. Untuk menyelesaikan masalah ini kita dapat berpegang pada Putusan Mahkamah Agung Reg. Nomor 1520K/Pdt/184 tanggal 31 Mei 1986 kemudian dalam putusan Mahkamah Agung Nomor 3309K/Pdt/1985 tanggal 29 Juli 1987 dan Putusan Mahkamah Agung Nomor 3454K/Pdt/1985 tanggal 4 Maret 1987 yang menyatakan bahwa akta pengakuan utang adalah akta yang harus dibuat Debitur sendiri secara sepihak.

Akta merupakan produk hukum yang dibuat oleh seorang Notaris. Berdasarkan ketentuan Pasal 1868 KUH Perdata akta otentik adalah: "Suatu akta otentik ialah suatu akta dibuat dalam 
bentuk yang ditentukan undang- undang oleh atau dihadapan pejabat umum yang berwenang untuk itu ditempat akta itu dibuat". Terdapat begitu banyak jenis akta yang dapat dibuat oleh seorang Notaris, salah satunya adalah akta pengakuan hutang. Ketentuan Pasal 1 angka 11 Undang-undang Nomor 2 Tahun 2014 tentang Jabatan Notaris yang mengatur mengenai akta pengakuan hutang menentukan bahwa "Grosse akta adalah salah satu akta untuk pengakuan utang dengan kepala akta "Demi Keadilan Berdasarkan Ketuhanan Yang Maha Esa" yang mempunyai kekuatan eksekutorial.

2. Hak Tanggungan Sebagai Jaminan Utang Piutang

Menurut Pasal 1 angka (1) Undang-undang Nomor 4 Tahun 1996, definisi hak tanggungan sebagai berikut: "Hak Tanggungan adalah hak jaminan yang dibebankan pada hak atas tanah sebagaimana dimaksud dalam Undang-undang Nomor 5 Tahun 1960 tentang Peratutan Dasar Pokok-pokok Agraria, berikut atau tidak berikut dengan tanah itu, untuk pelunasan hutang tertentu yang memberikan kedudukan yang diutamakan kepada kreditor tertentu terhadap kreditur-kreditur lain."

Dalam hak tanggungan sendiri terdapat subjek dan objek, yaitu;

a. Subjek Hak Tanggungan

Subjek hukum hak tanggungan diatur dalam ketentuan dalam Pasal 8 dan Pasal 9 Undang-undang Nomor 4 Tahun 1996 tentang Hak Tanggungan, yaitu sebagai berikut:

1) Pemberi Hak Tanggungan

Pemberi Hak Tanggungan adalah orang per orangan atau badan hukum yang mempunyai kewenangan untuk melakukan perbuatan hukum terhadap objek hak tanggungan yang bersangkutan.

2) Pemegang Hak Tanggungan

Pemegang Hak Tanggungan adalah orang perorangan atau badan hukum yang berkedudukan sebagai pihak yang berpiutang.

b. Objek Hak Tanggungan

Berdasarkan Undang-undang Hak Tanggungan, objek yang dapat dibebani Hak Tanggungan adalah hak-hak atas tanah beserta benda- benda yang berkaitan dengan tanah. Dalam Pasal 4 sampai dengan Pasal 7 Undang-undang Hak 
Tanggungan tersebut dijelaskan bahwa yang menjadi objek hak atas tanah yang dapat dibebani hak tanggungan adalah sebagai berikut:

1) Hak Milik;

2) Hak Guna Usaha;

3) Hak Guna Bangunan;

4) Hak Pakai atas Tanah Negara; dan

5) Hak-hak atas tanah berikut bangunan, tanaman dan hasil karya yang telah ada atau akan ada yang merupakan satu kesatuan dengan tanah tersebut, dan yang merupakan milik pemegang hak atas tanah.

3. Eksekusi Jaminan Utang Hak Tanggungan

Beberapa model eksekusi hak tanggungan adalah sebagai berikut: (Efendy, 2013)

a. Eksekusi Dengan Jalan Mendaku

Istilah "mendaku" disini kira-kira "menjadikanku yang mempunyainya". Sehingga yang dimaksud dengan eksekusi hak tanggungan secara mendaku adalah eksekusi hak tanggungan dengan cara mengambil barang objek hak tanggungan untuk dijadikan milik kreditur secara langsung tanpa melewati transaksi apapun.

Namun secara hukum eksekusi mendaku tidak lah dibenarkan. Undang-undang Hak Tanggungan melarang eksekusi mendaku sesuai dengan ketentuan Pasal 20 ayat (4) dari undang-undang tersebut yang menyatakan antar lain, bahwa setiap eksekusi selain dari yang dibenarkan dalam undang-undang itu batal demi hukum (null and volid).

b. Eksekusi Dengan Jalan Menjual Bawah Tangan Secara Langsung

Objek hak tanggungan dapat juga dieksekusi secara parate eksekusi (mengeksekusi tanpa lewat pengadilan) dengan cara menjual benda objek hak tanggungan secara langsung oleh kreditur di bawah tangan, asalkan terpenuhi syarat-syarat untuk itu. Menurut Undang-undang Hak Tanggungan Nomor 4 tahun 1996 Pasal 20 ayat (2) dan (3), syarat- syarat agar suatu objek hak tanggungan dapat dieksekusi secara langsung (di bawah tangan) adalah sebagai berikut:

1) Dilakukan berdasarkan kesepakatan antara pemberi 
dengan penerima hak tanggungan;

2) Jika dengan cara penjualan di bawah tangan tersebut dicapai harga tertinggi yang menguntungkan semua pihak;

3) Diberitahukan secara tertulis oleh pemberi dan/atau penerima fidusia kepada pihak-pihak yang berkepentingan;

4) Diumumkan dalam sedikit-sedikitnya dua surat kabar yang beredar di daerah bersangkutan dan/atau media massa setempat;

5) Pelaksanaan penjualan dilakukan setelah lewat waktu 1 (satu) bulan sejak diberitahukan secara tertulis oleh pemberi dan/atau pemegang hak tanggungan;

6) Tidak ada pihak yang menyatakan keberatan. Perlu diketahui bahwa pihak pemberi hak tanggungan yang semula sudah menyetujui proses eksekusi secara langsung tidak dapat mengubah pendapatnya dengan mengajukan keberatan terhadap proses eksekusi itu.

c. Eksekusi Degan Menjual Lelang Sendiri Oleh Kreditornya Tanpa Ikut Campur Tangan Kantor Lelang

Meskipun tidak ditegaskan didalam undang-undang, eksekusi objek hak tanggungan dapat juga dilakukan dengan jalan menjual lelang sendiri oleh krediturnya, tanpa ikut campur tangan kantor lelang maupun pengadilan.

d. Eksekusi Dengan Jalan Menjual Lewat Kantor Lelang Tanpa Perlu Campur Tangan Pengadilan.

Eksekusi hak tanggungan dapat juga dilakukan dengan jalan mengekesekusinya sendiri oleh pemegang hak tanggungan lewat lembaga pelelangan umum (kantor lelang), di mana hasil pelelangan tersebut diambil untuk melunaskan pembayaran utang-piutangnya.

e. Eksekusi Secara Fiat Eksekusi Melalui Pengadilan Ada beberapa akta yang mempunyai titel eksekutorial, yang disebut dengan istilah "grosse akta", yaitu sebagai berikut:

1) Akta hipotek (berdasarkan Pasal 224 HIR);

2) Akta Pengakuan Utang (berdasarkan Pasal 224 HIR);

3) Akta Hak Tanggungan (berdasarkan Undang-undang Hak Tanggungan Nomor 4 Tahun 1996);

4) Akta Fidusia (berdasarkan Undang-undang Fidusia Nomor 42 Tahun 1999). Menurut Kitab Undang-undang Hukum Acara Perdata (HIR), setiap akta yang mempunyai titel eksekutorial dapat dilakukan fiat eksekusi. 
f. Eksekusi Dengan Jalan Gugatan Perdata Biasa Melalui Pengadilan

Sekalipun tidak disebutkan dalam Undang-undang Hak Tanggungan, pihak kreditur tetap dapat menempuh prosedur eksekusi biasa lewat gugatan biasa ke pengadilan. Tidak ada indikasi sedikitpun dalam Undang-undang Hak Tanggungan khususnya tentang cara eksekusinya yang bertujuan meniadakan ketentuan hukum acara umum tentang eksekusi umum lewat gugatan biasa ke pengadilan negeri yang berwenang.

Sebagai tambahan, keberadaan model-model eksekusi khusus dalam Undang-undang Hak Tanggungan tersebut justru untuk mempermudah dan membantu pihak kreditur dalam menagih utang yang mempunyai jaminan hak tanggungan, dengan jalan mengeksekusi hak tanggungan tersebut.

\section{Analisis Yuridis Wanprestasi Terhadap Akta Pengakuan Utang Dibawah Tangan Yang Menjaminkan Sertifikat Hak Milik Atas Tanah Ditinjau Dari Pasal 12 Undang-Undang Nomor 4 Tahun 1996 Tentang Hak Tanggungan}

1. Kasus Posisi

Berkaitan dengan kasus yang penulis angkat, bermula pada saat saudari Sudarti meminjam uang kepada saudara Dadang sebesar Rp. 422.000.000 (empat ratus dua puluh dua juta rupiah) dengan jaminan Sertifikat Hak Milik Nomor 1243/Kel.Sukajadi. Akan tetapi saudara Dadang terlebih dahulu menyita Sertifikat Hak Milik Nomor 1243/Kel.Sukajadi tersebut, dimana saudara Dadang tidak mau mengembalikan sertifikat tersebut kepada saudara Sudarti, dan hanya mau menyerahkan photocopy sertifikat, itupun dengan syarat Sudarti diminta untuk menandatangani Surat Pernyataan Utang kepada Penggugat dengan sejumlah uang Rp. 422.000.000,- (empat ratus dua puluh dua juta rupiah) pada tanggal 7 Februari 2017 yang sudah disiapkan.

Dimana berdasarkan hal tersebut, maka ditanda tanganilah surat pernyataan utang tertanggal 07 Februari 2017 tanpa didahului dengan perjanjian pokok sebelumnya oleh Sudarti, yang isinya menyatakan bahwa benar Sudarti telah meminjam uang kepada Dadang sebesar Rp.422.000.000, dengan demikian 
atas utang tersebut Sudarti menjaminkan Sertifikat Hak Milik Nomor 1243 yang terletak di jalan R.A Kartini No.01 Rt.02/Rw.02 Kelurahan Sukajadi (dahulu Kelurahan Gunung Ibul Barat), Kecamatan Prabumulih Timur, Provinsi Sumatera Selatan sesuai dengan Surat Ukur Nomor 1561/sukajadi/2016 tanggal 15 Agustus 2016, luas $784 \mathrm{~m} 2$ atas nama Sudarti Mahanani berupa tanah dan bangunan, dan akan dilunasi dalam jangka waktu 6 (enam) bulan yaitu selambat-lambatnya pada bulan agustus 2017 .

Namun sampai waktu yang telah ditentukan Sudarti tidak juga memenuhi kewajibannya untuk melakukan pembayaran sebagaimana mestinya sesuai dengan surat pengakuan utang tersebut. Walaupun Dadang telah memberikan somasi kepada Sudarti, serta telah melakukan mediasi namun tidak juga menemukan titik terang. Sehingga pihak Dadang memilih untuk menggugat Sudarti ke Pengadilan Negeri Prabumulih atas perbuatan wanprestasi, berlanjut ketingkat banding diPengadilan Tinggi Palembang, hingga ditahap kasasi di Mahkamah Agung.

\section{Analisa Hasil Penelitian}

Dalam pengakuan utang tersebut terdapat hal-hal pokok yang diatur dalam Akta Pengakuan Utang diantaranya yaitu:

1) Bahwa benar Tergugat mempunyai hutang kepada Penggugat dengan sejumlah uang Rp.422.000,00 (empat ratus dua puluh dua juta rupiah);

2) Bahwa dalam jangka waktu 6 (enam) bulan tidak dapat diselesaikan maka agunan Sertifikat Hak Milik Nomor 1243/Kel.Sukajadi akan menjadi milik Penggugat.

Sehingga apa-apa yang dicantumkan dan diatur dalam Akta Pengakuan Utang tersebut merupakan suatu kesepakatan yang mengikat kedua belah pihak karena pada dasarnya suatu perjanjian akan menerbitkan perikatan bagi para pihak yang membuatnya (Asas Pacta Sunt Servanda).

Dalam kasus yang penulis angkat, terkait wanprestasi terhadap akta pengakuan utang dibawah tangan yang menjaminkan sertifikat hak milik atas tanah tanpa didahului perjanjian pokok dan pembebanan Hak Tanggungan, memaksa debitur untuk memberikan sertifikat hak milik atas sebidang tanah kepada kreditur, dan menjadikan sertifikat hak milik tersebut menjadi jaminan apabila debitur ingkar janji, dalam hal ini jaminan tersebut akan langsung menjadi milik kreditur 
seutuhnya tanpa ada nya transaksi apapun.

Jika ditinjau dari segi objek dalam surat pengakuan hutang tersebut, yang mana objeknya berupa hal yang terdapat dalam klausal kedua didalam pernyataan surat pengakuan hutang tertanggal 07 Februari 2017, yang menyatakan bahwa "Dalam jangka waktu 6 (enam) bulan tidak dapat diselesaikan maka agunan Sertifikat Hak Milik Nomor 1243/Kel.Sukajadi akan menjadi milik Penggugat."

Dimana berdasarkan hal tersebut yang menjadi jaminan atas hutang piutang antara debitur dan kreditur adalah berupa sebuah Sertifikat Hak Milik atas sebidang tanah dan bangunan Milik Nomor 1243/Kel.Sukajadi. Dalam pernyataan tersebut menyebabkan suatu akibat hukum, yaitu apabila ternyata debitur dinyatakan cidera janji, maka agunan atau jaminan atas Sertifikat Hak Milik tersebut akan segera menjadikannya milik kreditur.

Yang terpenting dan paling utama harus dipahami bahwa setelah diterbitkannya Undang-undang Nomor 4 Tahun 1996 Tentang Hak Tanggungan perlu diperhatikan lebih jauh, tanah sebagai jaminan atas utang telah diatur dalam Undang-undang Nomor 4 Tahun 1996 Tentang Hak Tanggungan beserta bendabenda yang berkaitan dengan tanah.

Sesuai dengan ketentuan Pasal 1 angka (1) Undangundang Nomor 4 Tahun 1996 tentang Hak Tanggungan maka hak atas tanah yang dijadikan jaminan untuk pelunasan utang tertentu harus dilakukan pembebanan Hak Tanggungan terlebih dahulu yang dibuat oleh Pejabat Pembuat Akta Tanah (PPAT) dengan melalui proses sesuai dengan yang ditentukan dalam Undang-undang tersebut diatas.

Serta mengingat ketentuan didalam Pasal 12 Undangundang Nomor 4 Tahun 1996 tentang Hak Tanggungan (UUHT) menyatakanbahwa; "Janji yang memberikan kewenangan kepada pemegang hak tanggungan untuk memiliki hak tanggungan apabila debitur cidera janji, batal demi hukum", yang serta merta menjadi suatu ketentuan mutlak didalam hal hutang piutang yang menjadikan tanah beserta bangunannya menjadi sebuah jaminan hutang, tidak bisalah dianggap sepele dan menjadikannya fatal apabila tidak diperhatikan dan dipahami secara seksama.

Sesuai kasus yang penulis angkat, ketentuan hal tersebut menjadikan objek didalam surat pernyataan hutang dibawah tangan tertanggal 07 Februari 2017, telah melanggar ketentuan 
Pasal $1320 \mathrm{KUH}$ Perdata terkait syarat sahnya perjanjian dalam point 4 mengenai klausal yang halal/suatu sebab yang tidak terlarang.

Selain itu, jika ditinjau dari eksekusi atas sebidang tanah yang ketentuannya berpacu pada Undang-undang Nomor 4 Tahun 1996 tentang Hak Tanggungan, dalam kasus diatas merupakan jenis eksekusi mendaku yang pun secara yuridis tidak dibenarkan.

Yang dimaksud dengan eksekusi hak tanggungan secara mendaku adalah eksekusi hak tanggungan dengan cara mengambil barang objek hak tanggungan untuk dijadikan milik kreditur secara langsung tanpa melewati transaksi apapun. (Efendy, 2013) Dalam hal tersebut tentu saja menurut hukum, eksekusi mendaku dalam Hak Tanggungan tidak dilegalkan, sesuai ketentuan Pasal 20 ayat (4) dari undang-undang tersebut yang menyatakan antar lain, bahwa setiap eksekusi selain dari yang dibenarkan dalam undang-undang itu batal demi hukum (null and volid).

Sehingga berdasarkan beberapa ketentuan yang dilanggar diatas terutama ketentuan Pasal 12 UUHT tersebut, sudah sepatutnya surat pernyataan utang tersebut dinyatakan batal demi hukum secara keseluruhan karena syarat objektif dalam pengakuan utang tersebut bertentangan dengan undang-undang, yang demikian pula sepatutnya putusan hakim yang menyatakan bahwa saudari Sudarti telah melakukan wanprestasi atas surat pernyataan utang tersebut pun batal demi hukum.

Dengan demikian Upaya Yang Dapat Dilakukan Jika

Terjadi Wanprestasi Dalam Surat Pengakuan Utang Dibawah Tangan Yang Menjaminkan Sertifikat Hak Milik Atas Tanah Tanpa Didahului Hak Tanggungan (Analisa Putusan Kasasi Nomor 837 K/Pdt/2019), yaitu:

a. Mengajukan Permohonan Eksekusi Hak Tanggungan berdasarkan Sertifikat Hak Tanggungan ini, melalui Pengadilan Negeri yang berwenang (jadi tidak perlu menempuh gugatan wanprestasi), yang dari permohonan ini Ketua Pengadilan Negeri akan mengeluarkan Penetapan Aanmaning (Teguran), agar debitur dalam jangka-waktu tertentu harus melunasi hutangnya seketika kepada kreditur;

b. Apabila berdasarkan Aanmaning ini debitur tetap lalai untuk melunasi kewajiban pembayarannya, maka Kreditur diperkenankan untuk mengajukan Permohonan Sita Eksekusi, 
dimana setelah sita eksekusi ini selesai diletakkan oleh Pengadilan, maka selanjutnya Kreditur akan mengajukan Permohonan Lelang kepada Pengadilan Negeri berwenang, agar bersedia menjual objek jaminan hutang yang telah dibebankan hak tanggungan tadi, melalui upaya lelang (yang dilakukan bekerjasama dengan Kantor Lelang Negara setempat).Namun jika perkara yang terjadi seperti didalam Putusan Kasasi Nomor 837 K/Pdt/2019, yang mana dalam kasus posisi sudah dijabarkan, bahwa pihak kreditur dan debitur melakukan suatu kegiatan pinjam meminjam sejumlah uang dengan menjaminkan sertifikat hak milik atas sebidang tanah milik debitur, namun tidak dibuatnya perjanjian pokok pinjam meminjam terlebih dahulu melainkan langsung dibentuknya suatu akta pengakuan utang dibawah tangan yang ditulis langsung oleh pihak debitur.

Sehingga, upaya yang dapat dilakukan apabila terjadi wanprestasi terhadap surat pengakuan hutang dibawah tangan yang menjaminkan sertifikat hak milik atas sebidang tanah tanpa didahuluinya perjanjian pokok dan pembebanan atas hak tanggungan, maka demi menjamin perlindungan hukum bagi kreditur atas pelunasan hutang debitur yaitu:

a. Pertama, kreditur dapat mengirimkan surat peringatan/somatie sebanyak tiga kali dengan harapan adanya itikad baik oleh debitur;

b. Kedua, terlebih dahulu melakukan upaya perdamaian diluar pengadilan, melihat subjek didalam perkara masih merupakan rekan seperkenalan, yang seyognyanya perdamaian merupakan upaya paling ideal untuk menyelesaikan sengketa perdata secara musyawarah mufakat. Terlebih, mediasi tetap akan dijadikan saran utama oleh hakim pengadilan apabila perkara tersebut dilanjutkan ke ranah litigasi, sesuai dengan ketentuan Peraturan Mahkamah Agung No. 1 Tahun 2008 tentang Prosedur Mediasi di Pengadilan.

c. Ketiga, apabila ternyata mediasi pun tidak menemukan titik terang, maka perkara bisa dapat dilanjutkan dengan gugat menggugat antara kedua belah pihak diranah litigasi

\section{KESIMPULAN}

Berdasarkan hasil pembahasan sebelumnya, setidaknya terdapat dua kesimpulan yang akan penulis jabarkan sesuai rumusan masalah, yaitu: 
Upaya yang dapat dilakukan jika terjadi wanprestasi dalam surat pengakuan utang dibawah tangan yang dibuat yang menjaminkan sertifikat hak milik atas tanah tanpa didahului hak tanggungan. Pertama, kreditur dapat mengirimkan surat peringatan/somatie sebanyak tiga kali dengan harapan adanya itikad baik oleh debitur; Kedua, terlebih dahulu melakukan upaya perdamaian diluar pengadilan, melihat subjek didalam perkara masih merupakan rekan seperkenalan, yang seyognyanya perdamaian merupakan upaya paling ideal untuk menyelesaikan sengketa perdata secara musyawarah mufakat. Terlebih, mediasi tetap akan dijadikan saran utama oleh hakim pengadilan apabila perkara tersebut dilanjutkan ke ranah litigasi, sesuai dengan ketentuan Peraturan Mahkamah Agung No. 1 Tahun 2008 tentang Prosedur Mediasi di Pengadilan. Ketiga, apabila ternyata mediasi pun tidak menemukan titik terang, maka perkara bisa dapat dilanjutkan dengan gugat menggugat antara kedua belah pihak diranah litigasi. Dengan memiminta saran dan putusan hakim yang sebaik-baiknya (a qua et bono), diantaranya meminta kepastian apakah surat pengakuan hutang dibawah tangan tersebut sah atau tidak sah dimata hukum, ditambah dengan adanya jaminan berupa hak katas tanah yang pemenuhannya haruslah berpatokan pada Undang-Undang Nomor 4 Tahun 1996 tentang Hak Tanggungan, selain itu dapat meminta penjatuhan parate eksekusi atas suatu hal yang dijaminkan, sehingga dengan adanya putusan pengadilan debitur tidak bisa menolak dan menyanggah perbuatannya.

Menurut penulis yang menjadi dasar pertimbangan hakim (Ratio Decidendi) dalam Putusan Kasasi Nomor 837K/Pdt/2019 tentang wanprestasi dalam pengakuan utang piutang dibawah tangan yang 
menjaminkan sertifikat hak milik atas tanah sudah sesuai dengan Pasal 12 Undang-undang Nomor 4 Tahun 1996 Tentang Hak Tanggungan ialah:

Jika dilihat dari hasil putusan kasasi yang menolak permohanan kasasi dari Pemohon Kasasi SUDARTI MAHANANI, atas putusan Pengadilan Tinggi Palembang yang menguatkan putusan Pengadilan Negeri Prabumulih. Sehingga yang menjadi dasar pertimbangan hakim yang dikuatkan hingga ditahap kasasi tersebut merupakan dasar pertimbangan hakim tingkat pertama di Pengadilan Negeri Prabumulih.

Bahwa alasan-alasan kasasi tersebut tidak dibenarkan, oleh karena setelah meneliti dengan seksama memori kasasi yang diterima tanggal 25 September 2018 dan kontra memori kasasi yang diterima tanggal 10 Oktober 2018 dihubungkan dengan pertimbangan Judex Facti dalam hal ini Pengadilan Tinggi Palembang yang menguatkan putusan Pengadilan Negeri Prabumulih tidak salah menerapkan hokum, dengan pertimbangan sebagai berikut:

Bahwa Tergugat dalam Konvensi mempunyai utang Rp.422.000,00 (empat ratus dua puluh dua juta rupiah) kepada Penggugat dalam konvensi dengan jaminan Sertifikat Hak Milik Nomor 1243/Kelurahan Sukajadi sebagaimana Surat Pernyataan Tergugat dalam konvensi tanggal 7 Februari 2017 dan ternyata Tergugat dalam Konvensi wanprestasi karena ternyata dalam jangka waktu 6 (enam) bulan tidak melunasi utangnya kepada Penggugat dalam Konvensi;

Bahwa jaminan utang tidak dapat langsung menjadi milik kreditur jika tidak dilunasi dalam jangka waktu yang diperjanjikan dan pelunasan utang dilakukan dengan penjualan jaminan secara lelang oleh pejabat yang berwenang;

Menimbang, bahwa berdasarkan pertimbangan di atas, ternyata putusan Judec FactiPengadilan Tinggi Palembang yang menguatkan dengan hukum dan/atau undang-undang, maka permohonan kasasi yang diajukan oleh Pemohon Kasasi SUDARTI MAHANANI tersebut harus ditolak;

Menimbang, bahwa oleh karena permohonan kasasi dari Pemohon Kasasi ditolak dan Pemohon Kasasi ada di pihak yang kala, maka Pemohon Kasasi dihukum untuk membayar biaya perkara dalam tingkat kasasi ini;

Memperthatikan Undang-undang Nomor 48 Tahun 2009 tentang 
Aria Dimas Harapan \& Andi Safira Yan Istiany,

Kekuasaan Kehakiman, Undang-undang Nomor 14 Tahun 1985 tentang Mahkamah Agung sebagaimana telah diubah dan ditambah dengan Undang-undang Nomor 5 Tahun 2004 dan perubahan kedua dengan Undang-undang Nomor 3 Tahun 2009 serta peraturan perundang- undangan lain yang bersangkutan.

\section{SARAN}

Setelah memaparkan materi diatas, penulis memiliki beberapa saran yang diantaranya:

Pertama, Perlulah bagi para pihak yang ingin melakukan kegiatan pinjam meminjam terutama dalam hal utang piutang, terlebih dahulu memahami setiap aturan dan norma hukum yang berlaku atas perbuatannya, sehingga tidak akan menimbulkan kerugian diantara para pihak yang mengikatkan diri dikemudian hari;

Kedua, Saran penulis terhadap calon kreditur dimasyarakat, walaupun terlihat sepele namun sering kali diabaikan, banyak diantara aktivitas berpiutang memilih untuk menggunakan jalan pintas dengan tidak membuat perjanjian utang piutang dihadapan notaris, atau membuat akta pengakuan utang dihadapan notaris yang disertai kuasa menjual, dengan lebih memilih membuat surat dibawah tangan dikarenakan cara tersebut lebih mudah dan murah namun yang pada akhirnya akan menimbulkan suatu hal yang tidak diinginkan oleh para pihak dikemudian harinya. Sehingga atas hal tersebut pernyataan bahwa "kuantitas menentukan kualitas" sangat berlaku dalam beberapa hal terutama dalam menentukan arah kepastian hukum dan perlindungan hukum diantara subjek utang piutang.

\section{DAFTAR PUSTAKA}

\section{Buku}

Abdulkadir Muhammad, 2010, Hukum Perdata Indonesia, Bandung : PT Citra Aditya Bakti.

Awalil Riky, 2008, Bank Subsidi Yang Membebani, Jakarta : E Pub,

Poerwadarminto, 2001, Kamus Besar Bahasa Indonesia, Jakarta : Balai Pustaka.

Departemen Pendidikan Nasional, 2005, Kamus Besar Ikthasar Indonesi Edisi Ketiga, Jakarta : Balai Pustaka, Jakarta.

Leli Joko Suryono, 2014, Pokok-Pokok Hukum Perjanjian Indonesia, Yogyakarta: LP3M UMY. 
Mgs. Edy Putra Tje'Aman, 1989, Kredit Perbankan,Yogyakarta: Liberty

Munir Fuady,2013, Hukum Jaminan Utang, Jakarta : Erlangga.

P.N.H.Simanjuntak, 2015, Hukum Perdata Indonesia: Edisi Pertama, Jakarta : Prenada media Group.

Satjipto Rahardjo,2000, Ilmu Hukum, Bandung : Citra Aditya Bakti,.

Soerjono Soekanto,2007, Pengantar Penelitian Hukum, Jakarta :UI Press.

Subekti, 2004, Hukum Perjanjian, cet.20, Jakarta : Intermasa.

Sudikno Mertokusumo, 1995, Mengenal Hukum : Suatu Pengantar, Yogyakarta : Liberty.

\section{Peraturan Perundang-Undangan}

Kitab Undang-undang Hukum Perdata

Undang-undang Nomor 4 Tahun 1996 tentang Hak Tanggungan

Putusan Kasasi Mahkamah Agung Nomor 837 K/Pdt/2019

\section{Artikel Seminar/Jurnal/Website}

Fransiska Nona Kartika, Analisis Mengenai Akta Pengakuan Utang Dengan Jaminan Hak Atas Tanah Yang Diikuti Kuasa Menjual (skripsi tidak diterbitkan), Universitas Indoensia, Depok, 2012.

I Made Dermawan, Upaya Hukum Terhadap Kreditor Atas Objek Hak Tanggungan Dari Upaya Sita Jaminan Oleh Pihak Ketiga Dalam Kepailitan, Jurnal Surya Kencana Satu: Dinamika Masalah Hukum dan Keadilan, Vol. 10 No. 2, Oktober 2018. 